\title{
ANALYSIS OF THE ECO-DYNAMIC STABILITY AND ENVIRONMENTAL FRAGILITY OF RIO CABAÇAL BASIN, MATO GROSSO STATE (MT), BRAZIL
}

\author{
Thiziane Helen LORENZON ${ }^{1}$ \\ Sandra Mara Alves da Silva NEVES ${ }^{1}$ \\ Jesã Pereira KREITLOW ${ }^{1}$ \\ Edinéia Aparecida dos Santos GALVANIN² \\ Luiz Carlos MACHADO FILHO
}

\begin{abstract}
Environmental planning studies are important tools used for the conservation of natural landscapes. The objective of this study was to evaluate the eco-dynamic stability and environmental fragility of the Cabaçal river basin, Mato Grosso State. The methodology of empirical analysis from the environmental fragility proposed by ROSS (1994) was applied, using geo-technologies for mapping the index of relief dissection, soils, land use/land vegetation cover, and climate. Approximately $60 \%$ of the area from the basin under study presents unstable eco-dynamic units. The Rio dos Bugres subbasin is the unit with the greatest landscape instability $(74.39 \%)$. The Rio Branco subbasin has the highest areal percentage of class Strong fragility (20.38\%). It is concluded that most of the extension of the Cabaçal River basin presents a high fragility and unstable eco-dynamic units which can compromise the environment in this important unit of the Upper Paraguay Basin and the Pantanal biome.
\end{abstract}

Key words: Environmental conservation. Environmental planning. Pantanal. Upper Paraguay Basin. Geo-technologies.

\footnotetext{
1 Universidade do Estado de Mato Grosso - UNEMAT/Campus Cáceres. Curso de Geografia. Laboratório de Geotecnologias UNEMAT. Av. Santos Dumont, s/n. Bairro: Santos Dumont. CEP: 78200-000, Cáceres/MT, Brasil - E-mails: thizianel@gmail.com; ssneves@unemat.br; jesapk1@hotmail.com.

2 Universidade do Estado de Mato Grosso - UNEMAT/Campus Barra do Bugres. Curso de Matemática. Laboratório de Geomática UNEMAT. Rua A, s/n. Bairro: Cohab São Raimundo. CEP: 78.390-000, Barra do Bugres/MT, Brasil - E-mail: galvaninbbg@unemat.br.

${ }^{3}$ Usinas Itamarati S/A - Departamento de Sistema de Gestão Integrado. Fazenda Guanabara Agrícola. Caixa Postal 60, s/n. Bairro: Zona Rural. CEP: 78.370-000, Nova Olímpia/MT, Brasil E-mail: luiz.carlos@uisanet.com.br
} 


\section{Resumo}

\section{Análise da estabilidade ecodinâmica e fragilidadade ambiental da bacia hidrográfica do Rio Cabaçal, Mato Grosso - Brasil}

Estudos de planejamento ambiental são importantes ferramentas utilizadas na conservação das paisagens naturais. Objetivou-se avaliar a estabilidade ecodinâmica e a fragilidade ambiental da bacia hidrográfica do Rio Cabaçal, Mato Grosso. Aplicou-se a metodologia de análise empírica da fragilidade ambiental proposta por Ross (1994), operacionalizada por meio das geotecnologias para a confecção de mapas de índice de dissecação do relevo, solos, uso da terra e cobertura vegetal e clima. Aproximadamente $60 \%$ de área da bacia de estudo apresentam unidades ecodinâmicas instáveis, sendo a sub-bacia do Rio dos Bugres a unidade com a maior instabilidade da paisagem $(74,39 \%)$. A sub-bacia do Rio Branco é a de maior porcentagem de área em Forte fragilidade $(20,38 \%)$. Concluiu-se que a maioria da extensão da bacia hidrográfica do Rio Cabaçal apresenta-se com forte fragilidade e unidades ecodinâmicas instáveis o que pode comprometer a dinâmica ambiental nessa importante unidade da Bacia do Alto Paraguai e no bioma Pantanal.

Palavras-chave: Conservação Ambiental. Planejamento ambiental. Pantanal. Bacia Alto Paraguai. Geotecnologias.

\section{INTRODUCTION}

The eco-geodynamic interactions have been affected by anthropic interference that causes changes in the natural components and consequently in the equilibrium state of its components. The study of changes in landscape elements such as geomorphology, land use, pedology, and pluviometric behavior are an alternative of broad application for the evaluation of environmental fragility. In this sense, the evaluation of the natural potential fragility is related to the natural landscape factors (SILVEIRA; OKA-FIOR, 2007, p.2), which according to Donha et al. (2006, p. 176) "should be evaluated in an integrated form, considering always the anthropogenic interventions modifying the natural environments".

Based on this assumption, the use of geo-technologies for the identification of environmental landscape change is an adequate recognition of the dynamics from the environment, enhancing the need of natural resources management and facilitating its historical evaluation (MARTINS; SILVA, 2007). Studies using geo-processing techniques to generate cartographic information and to investigate the environmental fragility demonstrate its applicability (SILVEIRA; CUNHA, 2010, p 562).

The adoption of a river basin as a basic management and planning field has been practiced by several authors (LUCIANO et al., 2014; SILVA et al., 2014) because it reflects better the geo-environmental characteristics and the changes resulting from anthropic uses. Thus, river basins confer an undeniable unit for studies of environmental fragility because they express subtle changes in their equilibrium.

From the perspective that all the environmental variables (relief, soil, climate, land use/vegetation cover) present both extreme and complex interdependence with the anthropic alterations, it is possible to categorize the environmental stability of the environment in different degrees of fragility. The synthetic product of this effort according to Franco et al. (2012, page 16) is a map of environmental fragility that allows the estimation of its potential in an integrated form, making it compatible with the natural features and its constraints.

In view of the above, the objective of this study is to evaluate both the ecodynamic stability and the environmental fragility of the Rio Cabaçal basin, Mato Grosso State. 


\section{MATERIAL AND METHODS}

\section{Area under study}

The study was developed in the Rio Cabaçal basin (RCB), with 5,662.11 km² (Figure 1), located in the SW Mato Grosso State (MATO GROSSO, 2012). In this hydrographic unit, there are three Brazilian biomes: Amazonia (83.03\%), Cerrado (12.22\%) and Pantanal (4.75\%), 6,034 springs, the main formers of the Pantanal, Permanent Protection Areas (PPA), the riparian forests, correspond to $49.5 \mathrm{~km}^{2}$ (LORENZON et al., 2015, p.150).

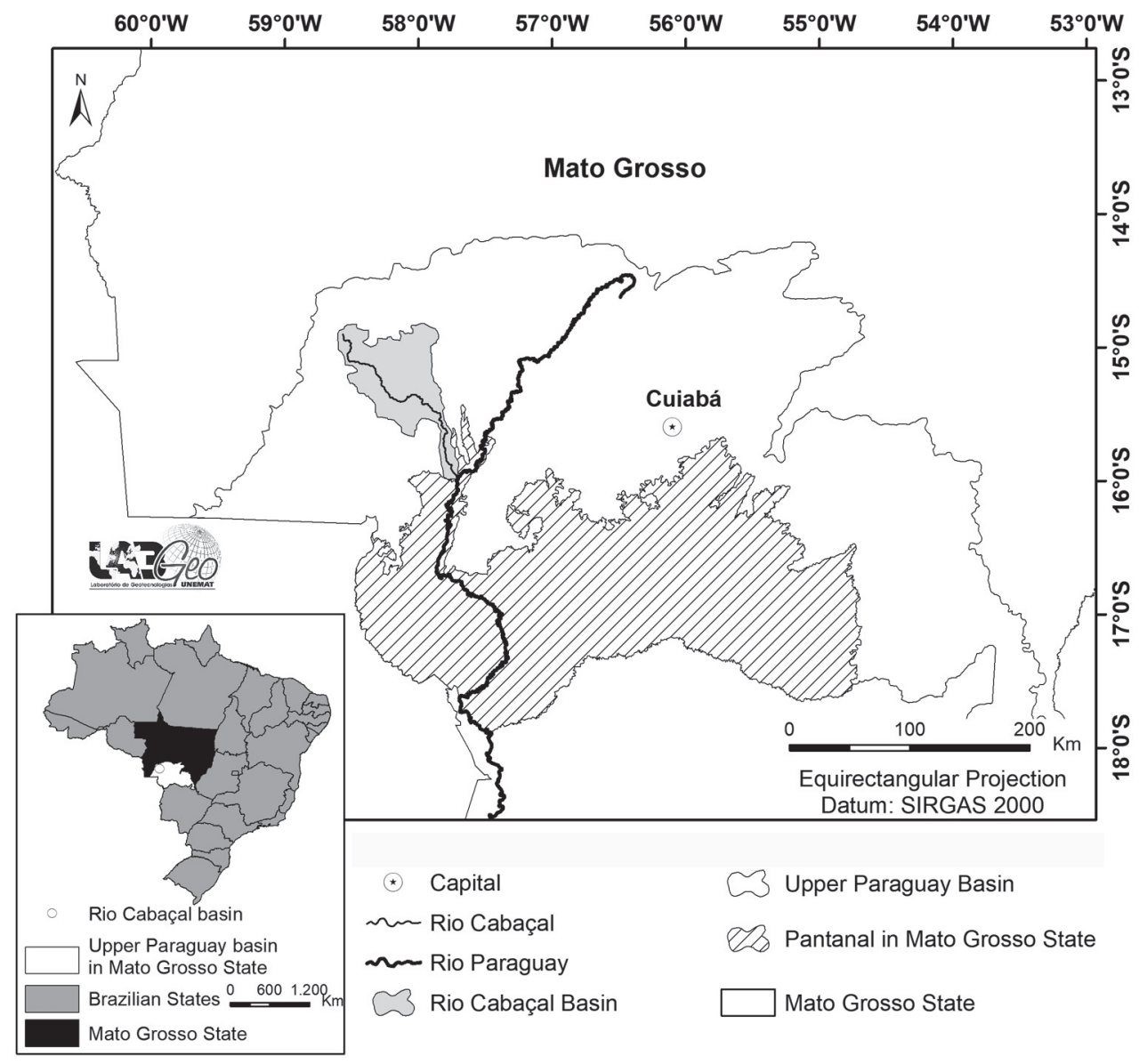

Figure 1 - Area of study in the context of the Upper Paraguay Basin in Mato Grosso and in relation to the Pantanal biome

in the state of Mato Grosso

Source: Authors (2016). 
The climate of the region is humid and tropical continental, with two well-defined seasons: alternately humid and dry, with climatic characteristic regularity (TARIFA, 2011).

The relief types are Flat to Gentle Rolling in the following geomorphologic units: Upper Paraguai Depression, Chapada dos Parecis, Planalto dos Parecis, and Pantanais Mato-grossenses (IBGE, 2006). The pedology is composed mainly by Acrisols followed by Oxisols and Quartz-arenic Arenosols (CARVALHO et al., 2014)

Rio Cabaçal, a tributary to Rio Paraguai, is the main water course of RCB with an extension of $303.43 \mathrm{Km}$. Its springs are located at Chapada dos Parecis and its main tributaries are: Branco $(103.67 \mathrm{Km})$, Vermelho $(103.62 \mathrm{Km})$ and Bugres $(79.81$ $\mathrm{Km}$ ). To summarize, there is a hydric net of $886.49 \mathrm{Km}$ in the extension of first and second order rivers from this basin.

The economy is essentially based on agro-livestock and sugarcane monoculture and livestock for breeding and dairy.

\section{METHODOLOGY}

In this study, the model of Empirical Analysis from Fragility of natural and anthropic environments proposed by Ross (1994) was used. The following cartographic bases were used: Soils (Pedology), Indexes of relief dissection (Geomorphology), Land Use/Land Cover and Climate (Rainfall). The cartographic products of soil and relief were obtained from the Secretary for Planning and General Coordination of Mato Grosso (MATO GROSSO, 2002), at scale 1:250.000.

In order to process information and clipping of hydrographic sub-basins of Rio Cabaçal, ArcGIS, version 10.5, (ESRI, 2017) was used. In this GIS, each vectorial file of themes was clipped for the area under study, and afterwards, classified according to the values and respective classes of fragility.

The relief dissection levels were suggested by Ross (1992), who classifies it considering the drainage density and the average interfluve dimension.

The elaboration of a land use/land cover map from the basin was done from a visual interpretation of 18 scenes from RAPIDEYE satellite from 2014, at $5 \mathrm{~m}$ spatial resoloution, donwloaded from IBAMA's geo-catalogue.

All procedures needed for the elaboration of a vegetation cover map were made with SPRING software, version 5.2.7 from INPE (CÂMARA et al.,1996). Initially, a geographic databank was created to store information. The defined cartographic parameters were: UTM coordinates and SIRGAS 2000 datum.

The scenes were imported to the GIS and clipped afterwards to the vector file from the area under study. For this procedure, no mosaicking of the images in the GIS was done due to limitations regarding the final image size, which surpasses the size supported by the software for files with .tif extension. After clipping, the scenes were segmented using the region growth method, considering the following parameters: similarity 700 and pixel area 700 .

The classification phase is composed by two distinct processes: in the first one, known as "Training", the elements present in the images allow the definition of thematic classes. According to Florenzano (2002), in this moment, texture, color, standard, form, and localization of the elements are analyzed for the definition of land use/land cover classes. The second process is the classification itself: the supervised method adopted was the classifier Bhattacharya, with an acceptance threshold of $99.9 \%$. 
Thereafter, mapping of thematic classes and the conversion matrix-vector was performed. The cartographic product underwent the cartographic generalization procedure $(1: 250,000)$ aiming to use it at the integrated analysis in order to obtain the environmental fragility of the area under study.

Using the maps prepared, the field surveys were performed during the dry and wet periods from years 2014 and 2015 to check ground truth. At the places visited, geographical coordinates were recorded with a GPS and photographies were taken. In the mean time, the analysis of the degree of soil protection was done in accordance with the proposals of Spörl (2011) and Ross (1994), and the degrees of soil protection presented by each class land use/land cover.

Rainfall data (climate) from the area under study were acquired from the map elaborated by Tarifa (2011), at 1:250,000 scale. The hierarchical levels of pluviometric behavior were based on Neves (2006).

The combination of vector files of the themes involved in the study was done with the tool Interesect of ArcGIS, resulting in the $\mathrm{mp}$ of environmental fragility. After that, the variables were hierarchized in five classes of fragility as proposed in the model. All variables received a digit varying from 1 to 5 . Thus, the composition of the relations from these four variables were obtained as follows: Relief dissection - very low (1) to very strong; Land use/land cover - protection level very high (1) to very low/nil (5); Pedology - fragility classes very low (1) to ver strong (5); climatology (rainfall) - very low (1) to very strong (5) according to Ross (1994).

The fragility classification, which characterizes different instability levels, was made through the combination between numeric digits of four information plans. The first one is related to relief, the second to soil, the third to land use/land cover and the fourth to climate (rainfall). planes.

A combination was made between two numerical digits of the four information

Thus, the variable Dissection of relief was determined, the degree of fragility of each area studied and the other variables define a hierarchy through its coefficients of fragility In this context, the variable Relief Dissection is the one that identifies the environments in which the natural and eco-dynamic balance were broken, which results in risk situations (SPÖRL; ROSS, 2004), and the other variables, according to Ross (1994), are those areas with greater criticality regarding natural potential.

In this way, four different degrees of fragility were determined - weak, medium, strong and very strong - that determine different eco-dynamic instabilities, evidencing those that were spared from human action and still remain in a state of dynamic equilibrium and those that suffered alteration of this balance, being areas of risk and imbalance (ROSS, 1990; ROSS, 1994; SPÖRL, 2007).

\section{RESULTS AND DISCUSSION}

The main relief dissection forms, pedology, vegetation cover, land uses and rainfall events found in the RBC are represented in figure 2.

In the study basin, there are three degrees of relief dissection: $2583.42 \mathrm{~km}^{2}$ are Weak (45.63\%), $1929.31 \mathrm{~km}^{2}$ are Average $(34.07 \%)$ and $1149.38 \mathrm{~km}^{2}$ are Strong $(20.3 \%)$. They correspond to the types and forms of relief of the fourth taxon, which are dissected with tops presenting convex, sharp and tabular morphologies, the latter 
one showing a low degree of fragility (ROSS, 1994). In contrast, the convex and sharp morphologies present a level of fragility identified as Strong, according to the same author.

Nine soil classes occur in the studied area, which fragility depends on their rocky formation and pedogenic forms and horizons (EMBRAPA, 2016), namely: 1182.53 $\mathrm{km}^{2}$ of Red Yellow Podzolic Alic (20.89\%), $1519.21 \mathrm{~km}^{2}(26.83 \%), 803.30 \mathrm{~km}^{2}$ of Quartz Alic Sand (14.19\%), $205.44 \mathrm{~km}^{2}$ of Alic Lithic Soils (3.63\%), $624.84 \mathrm{~km}^{2}$ of RedYellow Dystrophic Oxisol (11.04\%), 741.32 km2 Dark Red Dystrophic Oxisol (13.09\%), $151.97 \mathrm{~km} 2$ Eutrophic Cambisol (2.68\%), $392.31 \mathrm{~km} 2$ Dystrophic Alluvial Soils (6, $93 \%)$ and $41.18 \mathrm{~km} 2$ of Eutrophic Terra roxa $(0.73 \%)$. In this sense, the presence of $24.74 \%$ of soils classified with very strong fragility are present in the hydrographic unit, corresponding to $1401.05 \mathrm{~km}^{2}$ of area and representing classes of Alic Quartz sands, Alic lithic soils and Alluvial dystrophic soils.
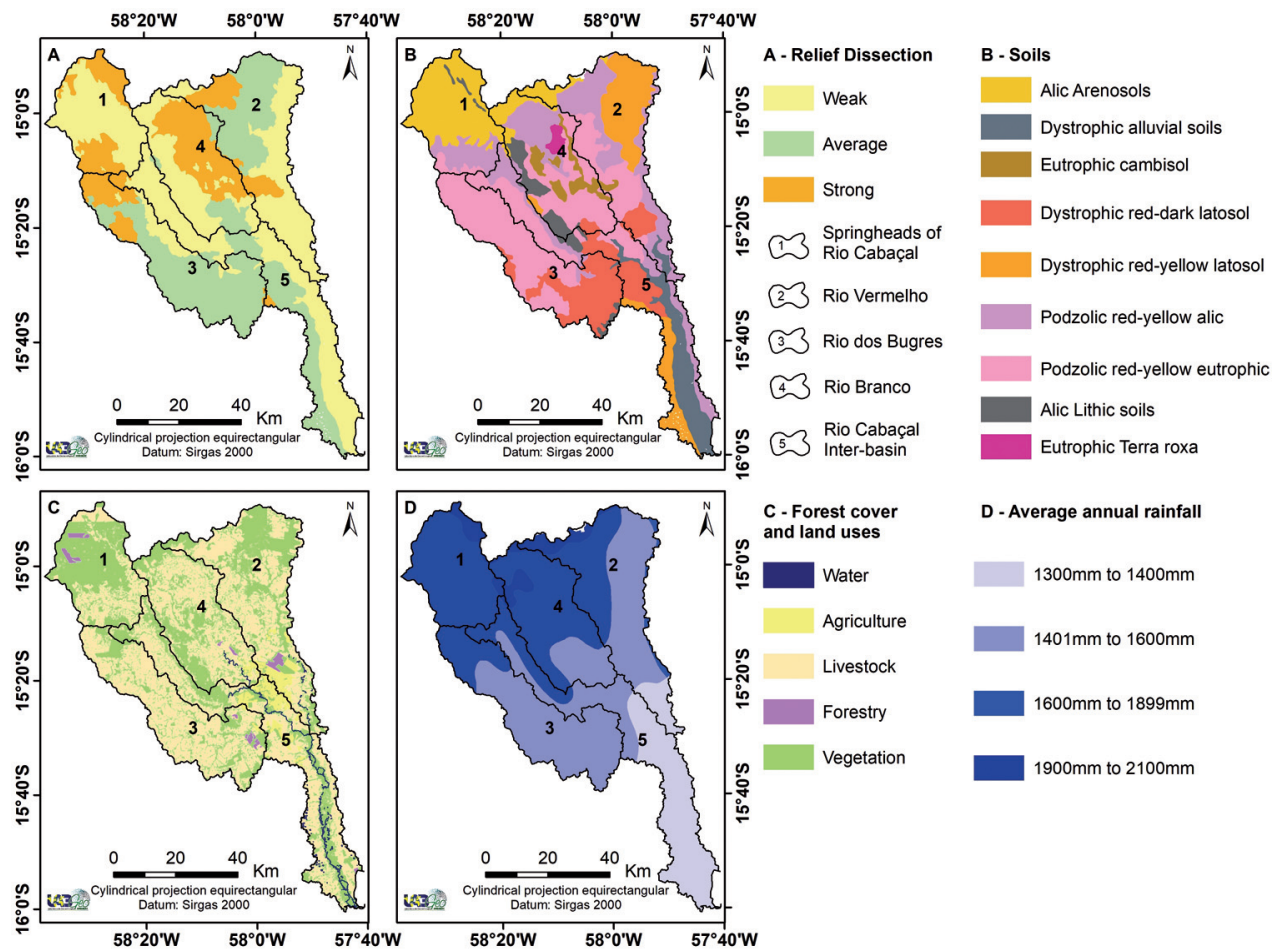

D - Average annual rainfall

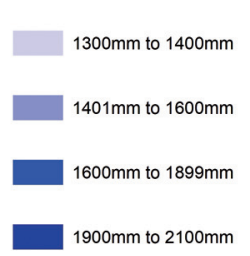

Figure 2 - Variables for the analysis of the environmental fragility of the Cabaçal River basin: A - Classes of relief dissection; B - Pedological units; C - Vegetation cover and land uses; And D - Precipitation distribution

Source: Authors (2016).

Vegetation cover and land uses represent five classes occurring in the basin under study: $16.52 \mathrm{~km}^{2}$ of Water $(0.29 \%), 216.90 \mathrm{~km}^{2}$ of Agriculture (3.83\%), 3081.77 $\mathrm{km}^{2}(54.43 \%), 54.19 \mathrm{~km}^{2}$ of Forestry $(0.96 \%)$ and $2292.72 \mathrm{~km}^{2}$ of Vegetation $(40.49 \%)$. Considering the land use established over an area, it is possible to determine the 
degree of criticality from the point of view of natural potential fragility. Environments weakened by human use normally demonstrate a suppression of their natural vegetation, configuring extreme vulnerability to episodes which transform their landscape.

Considering rainfall events, four patterns occur in the hydrographic unit investigated: $916.49 \mathrm{~km}^{2}(16.19 \%)$ of $1,300 \mathrm{~mm}-1,400 \mathrm{~mm}, 2,247.63 \mathrm{~km}^{2}(39.7 \%)$ of $1,401 \mathrm{~mm}-1,600 \mathrm{~mm}, 2,234,04 \mathrm{~km}^{2}(39.46 \%), 1.601 \mathrm{~mm}-1.800 \mathrm{~mm}, 263.96 \mathrm{~km}^{2}(4.66 \%)$, $1.900 \mathrm{~mm}-2.100 \mathrm{~mm}$, with a rainy period of four months (December to March) and a dry season of eight months (April to November). In this sense, it is inferred that intense rains, when allied to a relief with higher tops, present intense fragility due to the sliding events resulting from this geomorphology. Therefore, precipitation information is extremely important for the evaluation of the potentiality and the natural fragility of the environments.

According to Ross (1994), the variable plant cover determines the areas where the dynamic equilibrium has been broken, giving rise to risk situations as well as to areas where stability continues to reign (SPÖRL, 2011). In his studies on environmental fragility, ROSS (2009) explained that the breakdown of the ecological potential of a geo-system is directly related to the conditions of the natural physical environment, especially with the vegetation cover, and reveals the degradation potential caused by the human activities.

In this context, the catchment area of the Cabaçal River, considering that it presents more than $54 \%$ of its area classified as Medium and High fragilities, justifies that $59.7 \%$ of its units are characterized as environments with unstable eco-dynamics and different degrees of instability, which are concerns about the morphogenetic processes and mass movements that may occur in these scenarios (Table 1 and Figure 3).

\section{Tabela 1 - Landscape Stability of the RCB / MT sub-basins}

\begin{tabular}{cccc} 
Sub-basin & Estabilidade da Paisagem & Área ( Km $\mathbf{2})$ & Área (\%) \\
$\begin{array}{c}\text { Springheads } \\
\text { of Rio Cabaçal }\end{array}$ & Stable Eco-dynamic Units & 565,41 & 68,81 \\
\multirow{2}{*}{ Rio Branco } & Unstable Eco-dynamic Units & 256,23 & 31,19 \\
\multirow{2}{*}{ Rio Vermelho } & Stable Eco-dynamic Units & 415,06 & 40,32 \\
& Unstable Eco-dynamic Units & 614,31 & 59,68 \\
Rio dos Bugres & Stable Eco-dynamic Units & 556,24 & 41,01 \\
& Unstable Eco-dynamic Units & 800,09 & 58,99 \\
Rio Cabaçal & Stable Eco-dynamic Units & 556,24 & 25,61 \\
Inter-basin & Unstable Eco-dynamic Units & 800,09 & 74,39 \\
\hline
\end{tabular}

Source: Authors (2016).

On the other hand, $31.19 \%$ of its units demonstrated environments with stable eco-dynamics. These landscapes are characterized by different degrees of potential instability, that means that the natural balance has been preserved from human activities. 


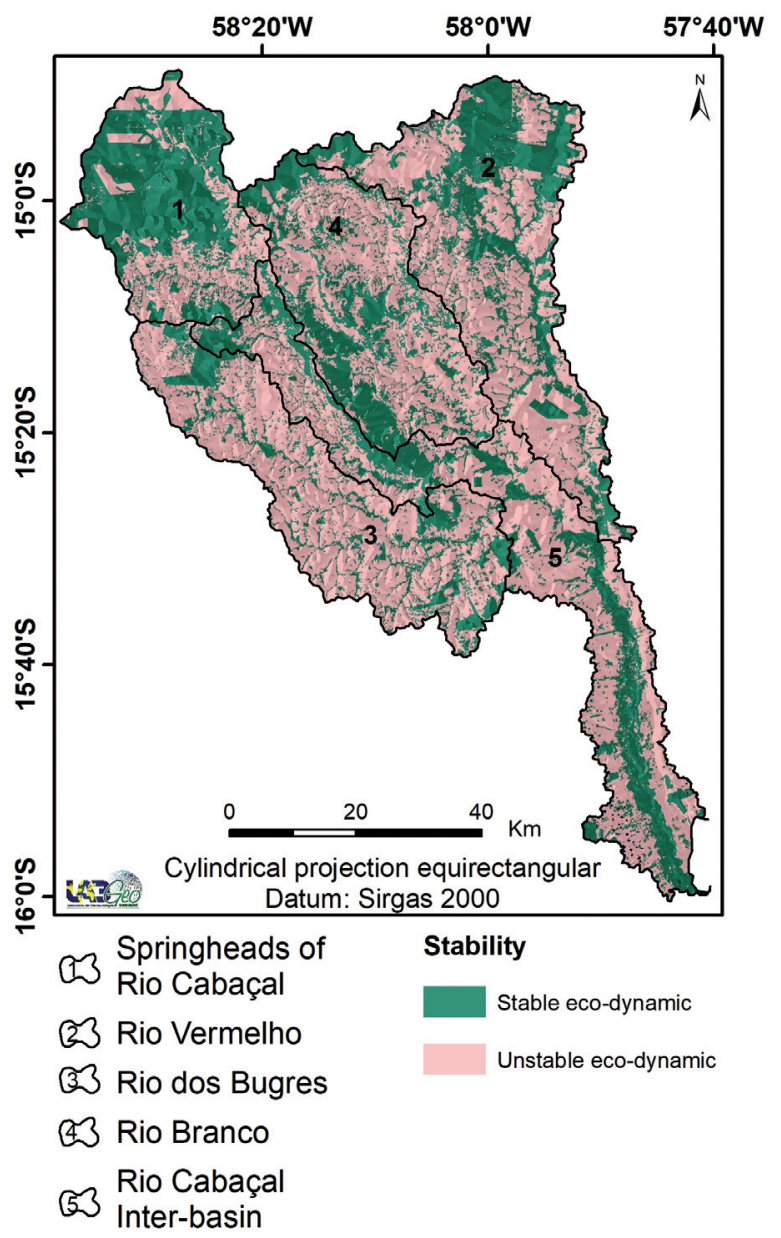

Figure 3 - Cartographic demonstration of the environmental stability of the RCB sub-basins

Source: Authors (2016).

The Springheads of sub-basin of Rio Cabaçal, which represents $67.05 \%$ of its area with weak fragility, shows $68.81 \%$ of stable eco-dynamic regions, which are basically justified by the maintenance of forest systems.

However, it was perceived the opposite in the other units, where it was possible to infer that human activities destabilized the dynamic balance of the same ones. In spite of the incipient human occupation, vegetation cover was replaced by pastures, agriculture, and forestry.

In the Rio Branco sub-basin, almost $60 \%$ of the landscape is covered by unstable eco-dynamic units. The gradual withdrawal of vegetation for the insertion, mainly of pasture, caused the environmental instability of these scenarios. 
A similar situation occurs in the Rio Vermelho subunit, in which $52.38 \%$ are in average too weak in their environments, demonstrating almost $59 \%$ of eco-dynamic instability in their landscape.

The sub-basin of Rio dos Bugres, presenting more than $89 \%$ of areas with Average and Strong fragilities, is characterized by $731.47 \mathrm{~km}^{2}$ occupied by pastures. Despite, these environments are not occupied by natural vegetation, they provide pastures. Though far from ideal, it is a cover with varied capacity of soil protection, contributing to the reduction of rainfall speed and increasing water infiltration (SPÖRL, 2011 , p. 104). Over $74 \%$ of this unit demonstrates the stability of the landscape with unstable eco-dynamics, where the natural conditions of vegetal cover were substituted by agro-livestock activities.

The Inter-basin of Rio Cabaçal presents $67.07 \%$ of weak fragility due to the characteristics of its relief and the maintenance of its natural reserves. Besides that, more than $68 \%$ of its units demonstrate stable eco-dynamics, when considering the stability of the landscape. It is important to maintain the natural vegetation in areas where the morpho-dynamics acts in the natural state, with the predominance of the processes of physical and chemical weathering under dense vegetation, and the impact of rainfall is attenuated by vegetation cover (SPÖRL, 2011, p. 81), thus causing the contamination of water bodies with toxic contaminants and sediments.

The RBC presents areas with degrees of environmental fragility classified as $2572.6 \mathrm{~km}^{2}$ Weak (44.43\%), $1918.52 \mathrm{~km}^{2}$ of Average $(33.88 \%)$ and $1154.21 \mathrm{~km}^{2}$ of Strong $(20.38 \%)$, including $0.3 \%$ water present in the cartographic product (Figure 4 ).

The fragilities of Middle and Strong levels found in the basin are usually justified by the presence of livestock in association with dissected relief forms with strong fragility. This convention, together with soil types such as Cambisols, Litholic, and Quartz Sands explain the vulnerability associated to this combination.

On the other hand, it is noteworthy that relief dissections with low fragility, if associated with extensive areas of vegetation, although with predominantly vulnerable soils, as in the case of Litholic soils and the Alic Quartz Sands, present generally low environmental fragility. Thus, spaces of low fragility are under a relief dissection index which presents a great stability, as it happens with the dissections with tabular and flat tops.

High intensity rainfall events ranging from 1,300 to $2,100 \mathrm{~mm}$ per year, when in high slope reliefs such as those found in the five sub-basins, lead to more intense erosion processes, that according to Nakashima (2001), favor the formation of furrows, sliding scars or even ravines or gullies connected to the headwaters of drainage that culminate in the increase of the environmental fragility.

The different land uses as a substitute for natural vegetation are of fundamental importance to change the degree of fragility from the environment. ABRÃO et al. (2015) warn that human action constitutes a large increase in the ranking of Medium and High fragilities in studies about the degree of potential environmental fragility.

The use of modified land by human interventions results in a medium to low degree of soil protection, which contributes to the classification of environmental fragility as very high (SANTOS et al., 2010).

From the five subunits of RCB, only the Rio Branco sub-basin presented the Strong class $(44 \%)$ in a higher percentage than the other ones due to the extensive area of Livestock associated with the Red-Yellow Podzolic Soils and the Eutrophic Terra Roxa, with a medium fragility degree. 


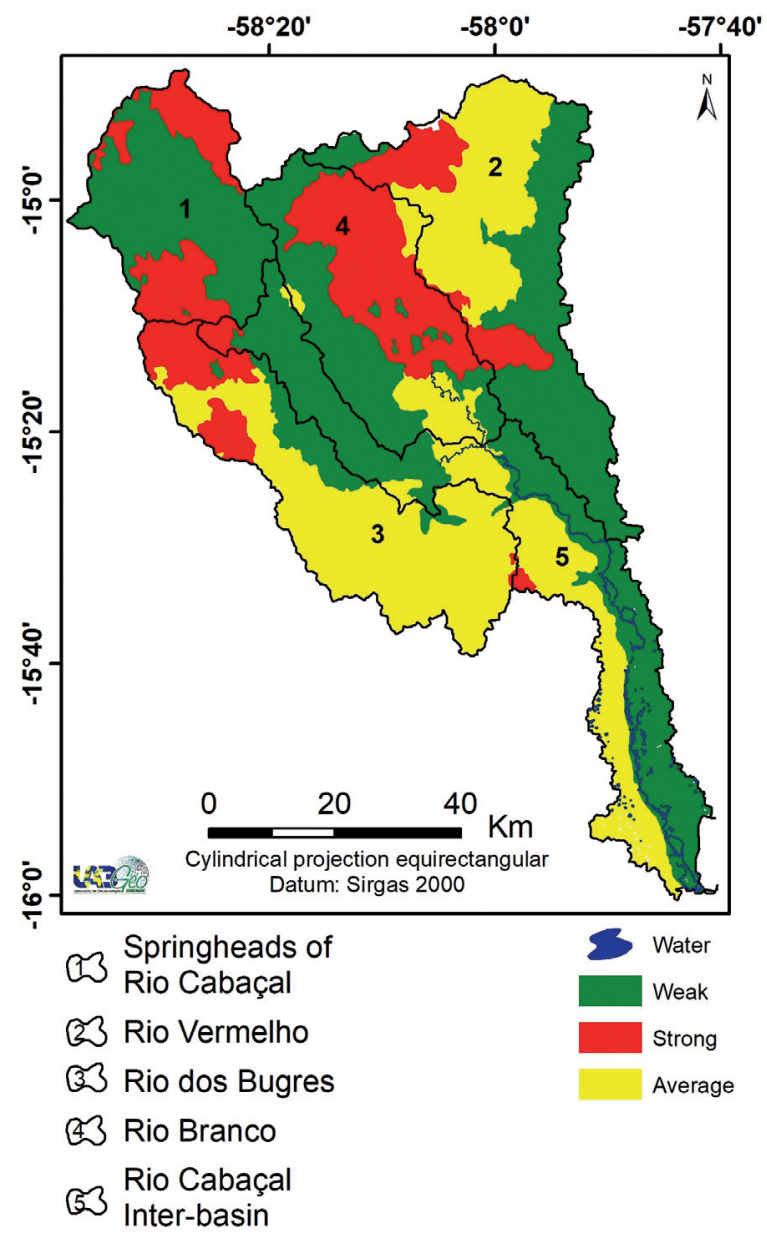

\section{Figure 4 - Environmental fragility in the} five sub-basins of the RCB

Source: Authors (2016).

The Springheads of sub-basin of Rio Cabaçal showed almost $33 \%$ of its area with fragility considered Strong, a consequence that $79.33 \%$ of the unit are pastures on Red-Yellow Podzolic soils and over $48 \%$ Alic Arenosols. The latter one shows strong instability (CREPANI et al., 2000) and great susceptibility to erosion (EMBRAPA, 2009), which confers an intense degree of fragility.

In contrast, more than $67 \%$ of the unit has a weak environmental fragility as a consequence of the fact that $43.63 \%$ of its area is covered with natural forest remnants.

The presence of pastures and forestry practices in soils of the quartz sand type (Quartzarenic Arenosols), a class with a high level of fragility, is a concern. SARTORI et al. (2005, p.15) warn on the insertion of crops in these soils, since they are characterized by a high permeability and susceptibility to erosion. Studies of susceptibility 
to water erosion developed by Nunes et al. (2013, p. 199) in the municipality of Salto do Céu, partially inside RBC, identified the Arenosols and Nitosols as high erodibility classes.

The removal of the natural vegetation cover increases the erosion rates, which causes greater surface runoff of substances and consequently an alteration in the sedimentation process. According to Taylor et al. (2008), areas with vegetation suppression increase drastically the amount of sediment reaching the water bodies.

Nevertheless, these areas are associated with relief forms dissected with tops presenting convex morphologies that confer a low level of fragility.

The Rio Vermelho sub-basin, with the largest area $\left(1356.33 \mathrm{~km}^{2}\right)$, shows $47.73 \%$ of its unit with weak fragility. However, the Medium and Strong ranks together account for more than $52 \%$ of area.

Red-Yellow Podzolic Eutrophic soils that despite its high fertility are able to erosion (EMBRAPA, 2009), are present in more than $325 \mathrm{~km}^{2}$ of the sub-basin. They are intermediate soils for Oxisols, showing intense depth. When in association with livestock, as in about $166 \mathrm{~km}^{2}$ of this unit, they are classified as with Strong fragility.

The sub-basin of Rio dos Bugres presents $72.6 \%$ of its area with medium fragility. However, the unit exhibits $89.21 \%$ of its area with grades ranging from Medium to Strong. Activities such as livestock, forestry and agriculture, and essentially the sugar cane monoculture, are present in large areas of Acrisols (Red-Yellow Podzolic Eutrophic), Oxisols (Dystrophic Dark Red/Eutrophic Oxisols) and Arenosols (Alluvial dystrophic soils). They are, moreover, inserted in relief dissections with high instability and with convex morphologies.

The highest degree of fragility was found in the Rio Branco sub-basin (44\% of its area), which livestock and agriculture activities are especially associated with highly fragile and unstable Nitosols and Cambisols. Salomão et al. (2009) observed in their study that the Nitosols and Cambisols, because they are shallow and porous soils, tend to reduce the infiltration of rainwater, allowing the sub-surface flow of the agrochemicals, configuring a threat to the water bodies. This justifies the attribution of high environmental fragility associated with this soil class.

According to the Brazilian Agency for Agricultural Research (EMBRAPA 2009), Nitossolos (Eutrophic Terra roxa), when associated to the undulated relief sites, present a greater risk of erosion as it is the case of the sub-unit analyzed.

The Rio Cabaçal inter-basin is the least compromised with episodes of fragility, considering that the fragility in over $61 \%$ of the extension of this area is Low. This inference is due to the geomorphology of the area, which relief types are flat and tabular and there is the presence of environments with maintenance of vegetation cover. Areas occupied by activities such as livestock and agriculture, despite in different soil classes and considering their respective degrees of fragilities are in a relief with low fragility.

\section{FINAL CONSIDERATION}

In the RCB landscape, it predominates the unstable eco-dynamic stability evidencing that the human action implied in the loss of the dynamic balance. In those sub-basins with a lower degree of human intervention, such as those covered by natural vegetation and forestry, a lower index of Environmental fragility showed the importance of maintenance of the vegetation cover. 
In the catchment area of Rio Cabaçal, there is a Low degree of environmental fragility, although there are areas showing degrees varying from Medium to High, constituting a source of concern regarding the growth of human actions in the region.

\section{ACKNOWLEDGMENTS}

We used information derived from Project modeling environmental indicators for the definition of priority and strategic areas for the recovery of degraded areas in SW Mato Grosso State. This project is connected to the subnet of social, environmental, and technological studies for the production system of SW Mato Grosso (REDE ASA), funded in the frame of edict MCT/CNPq/FNDCT/FAPs/MEC/CAPES/PRO-CENTRO-OESTE no $031 / 2010$. Data from this project contributed to the execution of this study.

\section{REFERENCES}

ABRÃO, C. M. R.; FERNANADES, E. F. L.; BACANI, E. M.; SILVA, J. F. Geotechnologies applied to mapping of environmental fragility in the Desbarrancado river basin, MS. Geografia, Rio Claro, v. 40, Número Especial, p. 9-26, 2015.

CÂMARA, G.; SOUZA, R. C. M.; FREITAS, U. M.; GARRIDO, J. SPRING: Integrating remote sensing and GIS by object-oriented data modeling. Computers \& Graphics, v. 20, n. 3, p. 395-403, 1996.

CARVAlho, J. M.; Cuiabano, M. M.; NEVES, R. J.; SERAFiM, M. E.; NEVES, S. M. A. S. Conflitos de uso da terra na bacia hidrográfica do rio Cabaçal - MT, Brasil. In: SIMPÓSIO DE GEOTECNOLOGIAS NO PANTANAL, 5., 2014, Campo Grande/MS, Anais... São José dos Campos: INPE, 2014, p. 166-176.

CREPANI, E.; MEdeiRos, J. S.; AZEVEdo, L. G.; DUARTE, V.; HERNANDEZ, P.; FLORENZANO, T.; BARBOSA, C. Sensoriamento remoto e geoprocessamento aplicados ao zoneamento ecológico-econômico e ao ordenamento territorial. INPE, São José dos Campos, SP, 2000.

DONHA, A. G.; SOUZA, L. C. DE P.; SUGAMOSTO, M. L. Determinação da fragilidade ambiental utilizando técnicas de suporte à decisão e SIG. Revista Brasileira de Engenharia Agrícola, v. 10, n. 1, p. 110-121, 2006.

EMBRAPA. Centro Nacional de Pesquisa de Solos. Sistema Brasileiro de Classificação de Solos. 2. ed. Rio de Janeiro: EMBRAPA, 2009. 412p.

ESRI. ArcGIS Desktop Advanced: release 10.4.1. Redlands, CA: Environmental Systems Research Institute, 2017.

FLORENZANO, T. G. Interpretação de Imagens. In: FLORENZANO, T. G. Imagens de satélite para estudo ambientais. São Paulo: Oficina de textos, 2002. p. 41-54.

FRANCO, G. B.; BETIM, L. S.; MARQUES, E. A. G.; GOMES, R. L. G; CHAGAS, C. S. Relação qualidade da água e fragilidade ambiental da Bacia do Rio Almada, Bahia. Revista Brasileira de Geociências, v. 42, n. 1, p. 114-127, 2012.

IBGE. Instituto Brasileiro de Geografia e Estatística. Mapa de unidades de relevo do Brasil. 2 ed. Rio de Janeiro: IBGE, 2006. Disponível em: <ftp://geoftp.ibge.gov.br/ mapas_tematicos/mapas_murais/relevo_2006.pdf>. Acesso em: 5 jun. 2016. 
LOREnZON, T. H.; PAIVA, S. L. P.; NeVES, S. M. A. S.; NEVES, R. J.; NUNES, E. S. Analysis of the conservation state from the Permanent protection areas at the springheads and of the water from Cabaçal river drainage basin, Mato Grosso State, Brazil. Geografia, Rio Claro, v. 40, Número Especial, p. 159-175, 2015.

LUCIANO, A. C. S.; SILVA, J. S. V.; NEVES, S. M. A. S. Geotecnologias aplicadas na caracterização e diagnóstico da paisagem da Upg do rio Aporé, MS. Revista Geopantanal, v. 1, n. 16, p. 57-75, 2014.

MARTINS, M. H. B.; SILVA, S. F. Uso de Imagens dos satélites CBERS-2 e Landsat V para mapeamento do Desflorestamento no Município de Ipixuna/AM: uma proposta metodológica para a Fiscalização Ambiental na região Amazônica. In: SIMPÓSIO BRASILEIRO DE SENSORIAMENTO REMOTO, 13, 2007, Florianópolis. Anais... São José dos Campos: INPE, 2007. 1, 4021-4028.

MATO GROSSO (Estado). Bases cartográficas temáticas - 1:250.000. DSEE: Diagnóstico Socioeconômico-Ecológico. Cuiabá: Secretaria de Estado de Planejamento e Coordenação Geral de Mato Grosso, 2012. Disponível em: <http:// www.seplan.mt.gov.br/ seplandownloads/index.php/dsee/viewcategory/1-arquivostematicos>. Acesso em: 10 mar. 2016.

MATO GROSSO (Estado). Secretaria de Estado de Planejamento e Coordenação Geral. Plano de Longo Prazo de Mato Grosso: macro-objetivos, metas globais, eixos estratégicos e linhas estruturantes. In: Prado, J. G. B.; Bertchieli, R.; Oliveira, L. G. (Orgs). Plano de Longo Prazo de Mato Grosso. Cuiabá/MT: Central de Texto, 2012. 108p. Disponível em: <http://www.seplan.mt.gov.br/mt20/mt20.htm>. Acesso em: 22 mar. 2016.

NAKASHIMA, M. S. R. Carta de fragilidade ambiental da bacia do rio Keller, Estado do Paraná: subsídio ao estudo dos processos erosivos. Acta Scientiarum, v. 23, n. 6, p. 1547-1560, 2001.

NEVES, S. M. A. S. Modelagem de um banco de da-dos geográficos do Pantanal de Cáceres/MT: estudo aplicado ao turismo. Rio de Janeiro, 2006. 284p. Tese (Doutorado em Geogra-fia) - Instituto de Geociências. Universidade Federal do Rio de Janeiro, Rio de Janeiro, 2006.

NUNES, M. C. M.; NEVES, S. M. A. S.; NEVES, R. J.; KREITLOW, J. P.; CHIMELLO, A. M. Susceptibility to water erosion of soils from the municipality Salto do Céu, SW Mato Grosso State, Brazil - Brazil. Geografia, Rio Claro, v.38, Número Especial, p.191206. 2013.

ROSS, J. L. S. O registro cartográfico dos fatos geomórficos e a questão da taxonomia do relevo. Revista do Departamento de Geografia, Sâo Paulo, v. 1, n. 6, p. 1729, 1992.

ROSS, J. L. S. Análise empírica da fragilidade dos ambientes naturais e antropizados. Revista do Departamento de Geografia , Sâo Paulo v. 1, n. 8, p. 64-74, 1994.

ROSS, J. L. S. Ecogeografia do Brasil: subsídios para o planejamento ambiental. São Paulo: Oficina de Textos, 2009.

SANTOS, R. M.; NÓBREGA, M. T.; PAIVA, R. G.; SILVEIRA, H. Análise da fragilidade ambiental no município de Tamboara - PR: aplicação e estudo comparativo de duas metodologias. Geoambiente, v. 3, n.14, p. 93-120, 2010.

SARTORI, A.; LOMBARDI NETO, F.; GENOVEZ, A. M. Classificação hidrológica de solos brasileiros para a estimativa da chuva excedente com o método do serviço de conservação do solo dos Estados Unidos parte 1: Classificação. Revista Brasileira de Recursos Hídricos, v. 10, n. 4, p. 05-18, 2005. 
SILVEIRA, A.; CUNHA, C. M. L. da. Análise empírica de fragilidade ambiental em área de expansão urbana: o caso do setor noroeste do sítio urbano de Piracicaba (SP). Geografia, Rio Claro, v. 35, n. 3, p. 553-572, 2010.

SILVA, J. S. V; NEVES, S. M. A. S.; Vendrusculo, L. G. Caracterização ambiental da unidade de planejamento e gerenciamento do rio Amambaí. Revista Geopantanal, v. 1, n. 16, p. 21-35, 2014.

SILVEIRA, C. T.; OKA-FIORI, C. Análise empírica da fragilidade potencial e emergente da bacia do rio Cubatãozinho, estado do Paraná. Caminhos da Geografia, v. 8, n. 22, p. 1-17, 2007.

SPÖRL, C. Análise da Fragilidade ambiental relevo-solo com aplicação de três modelos alternativos nas altas bacias do rio Jaguari-Mirim, Ribeirão do Quartel e Ribeirão da Prata. São Paulo, 2011. 165 f. Dissertação (Mestrado em Geografia) - Faculdade de Filosofia e Ciências Humanas. Universidade do Estado de São Paulo, São Paulo, 2011.

SPÖRL, C.; ROSS, J. L. S. Análise comparativa da fragilidade ambiental com aplicação de três modelos. Revista Geousp. v. 10, n. 15, p. 39-49, 2004.

TARIFA, J. R. Mato Grosso: clima: análise e representações cartográficas. Entrelinhas, 2011. 102p.

TAYLOR, K. G.; OWENS, P. N.; BATALLA, R. J.; GARCIA, C. Sediment and contaminant sources and transfers in river basins. Sustainable Management of Sediment Resources, v. 4, n. 1, p. 83-135, 2008. 